PRODUCTION

ENGINEERING

ARCHIVES
2015, Vol. 9, No 4, pp 35-37

ISSN 2353-5156

ISSN 2353-7779 (print version)

(online version)

Article history: $\quad$ Received: 16.11 .2015

Accepted: 11.12.2015

Online: 31.12 .2015

Available online on: http://www.qpij.pl

Exist since $4^{\text {rd }}$ quarter 2013

\title{
The issue of wooden and concrete railway sleepers utilization
}

\author{
Kinga Brózda ${ }^{1}$, Jacek Selejdak ${ }^{2}$ \\ ${ }^{1}$ Czestochowa University of Technology, The Faculty of Civil Engineering, Department of Building Structures and Engineering, \\ Akademicka 3, 42-200 Czestochowa, Poland, brozda.kinga@gmail.com \\ ${ }^{2}$ Czestochowa University of Technology, The Faculty of Civil Engineering, Department of Building Structures and Engineering, \\ Akademicka 3, 42-200 Czestochowa, Poland, jaceksel@poczta.onet.pl
}

\begin{abstract}
The high degree of degradation of the surface of the existing rail road causes the intensification of the modernization works. Due to modernization of the railway track, damaged parts of trackway are replaced with new ones. It causes waste generation of which a significant part are railway sleepers. The paper pointed the aspects relating to the utilization of railway sleepers made of wood and concrete. The associated environmental impact was also noted. In addition, the selected solutions which increasing the durability of railway sleepers were analysed.
\end{abstract}

Key words - utilization of railway sleepers, concrete and wooden sleepers, durability

\section{Introduction}

Railway sleepers are one of most important part of the basic bearing railway elements in the railway line. One of their tasks is resist the movements in the transverse and longitudinal directions throughout the railway grid. Moreover, in addition to ensuring an appropriate alignment of rails relative to one another, sleepers bear all dynamic and static impacts coming from the rails under the loads of the rolling stock and next transmit those loads for the gravel support bed.

The high degradation and destruction degree of the existing railway surfaces entails intensification of modernization works. Dispose of used railway sleepers represent a serious environmental problem. It refers to both of useless sleepers, made of concrete and wood. Especially wooden sleepers are problematic, because of contained therein chemical means used for impreg- nation. Necessity waste management is one of the major challenges of modern civilization. Particularly on the assumption, that railway sleepers, especially the wooden, are classified as hazardous waste (KLIMECKA-TATAR D. 2015), (KRAsiŃSKA A., KRÓL A., KUKULSKA - ZAJĄC E. 2014).

\section{Utilization of wooden railway sleepers}

Impregnated railway sleepers account for a significant part of the waste resulting from the increase in application of concrete sleepers during the modernization works. Durability of wooden sleepers has also its limit. It is estimated that in Poland shelf life Durability of wooden sleepers also has its limit. It is estimated that in Poland shelf life amounts to 25-30 years for hardwood and 18-21 years for softwood. In order to 
enhance the durability, wooden railway sleepers are saturated with creosote oil, which is recognized as non-threshold carcinogen. In addition, it is classified as a carcinogen (IB category), and what I more, some of its polycyclic aromatic hydrocarbons, as toxic and bioaccumulative (KRASIŃSKA A., KRÓL A., KUKULSKA - ZAJĄC E. 2014), (SANCEWICZ S. 2010).

Wood sourced from impregnated sleepers may not be used inside any buildings or places where it is possible to contact with the skin, including parks and gardens, recreational facilities, and especially not on playgrounds. One of solutions for the problem of disposing wooden sleepers is their storage in places suitable for hazardous waste. However, it is most environmentally unfriendly method. As other solution, can be also considered to dispose by incineration or other biological either chemical processing. (HOLEWA J., KUSINA E., KRASIŃSKA A. 2008).

\section{Utilization of concrete railway sleepers}

After removing concrete railway sleeper from a trackway, it becomes to be unusable. It is not suitable to be built into the foundations, due to its block character. Its shape makes it impossible to bricklaying and additionally, because of the heavy weight and small size, it is impossible to use it in road construction. For railway track which classes match 0,1 and 2, the shelf life of concrete sleepers is estimated at 35 years. Whereas for the other classes it is 40 years.

To obtain a useful recycled product, the recovery of the material by crushing is used. The crumbling of concrete sleepers is not difficult, but the problem is to skillfully separate concrete from steel reinforcement and remove it with the other of structural elements. The process consists in sleepers crushing, then the materials separation and the re - separation during transportation the material on the conveyor belts. After grains shaping by using an impact crusher and screening, powdered concrete is obtained. After water is added, powder hardens and by stabilizing by the cement, the consumption of the cement can be save by $50 \%$. Moreover, the crushed materials can be used again as a road substructure. The final product is equivalent to natural rocks, such as melaphyre (PŁONKA P. 2009).

\section{Durability of railway sleepers}

To reduce the number of waste from the railway sleepers, it is advised to obtain an appropriate and enhanced durability of track sleepers (BASZKIEWICZ K., SELEJDAK J. 2015).

Wooden sleepers have elastic - plastic characteristic, which gives rise to good dampen vibrations because of prolonged absorbing the energy from the wheels of rail vehicles on gravel support bed (ballast) and track bed. Despite all these good properties of wooden sleepers, there are a wide variety of external factors that influenced in a manner being disadvantageous on sleeper's durability (CZYCZUŁA W., DERKOWSKI W., ChUdyBa Ł. 2015), (JAWORSKA A., MilCZAREK D., NADUK E. 2013). During the establishment of new railway routes, to protect the environment, the fields of application wooden sleepers were restricted to railway tracks on curves with small radius. Therefore sleepers made of concrete are increasingly used (BASZKIEWICZ K., SELEJDAK J. 2015). Unfortunately, due to their elastic - brittle characteristics, deformations of substructure and supporting bed are increased (KWIATKOWSKA E. 2011).

To reduce the dynamic loads, which significantly affecting on gravel support bed and track bed, there is possible to apply concrete sleepers with special vibration - insulation (BASZKIEWICZ K., SELEJDAK J. 2015). Vibration - isolated layer is formed of elastic - plastic material, which is permanently connected with the lower surface of the railway sleeper (Fig. 1).

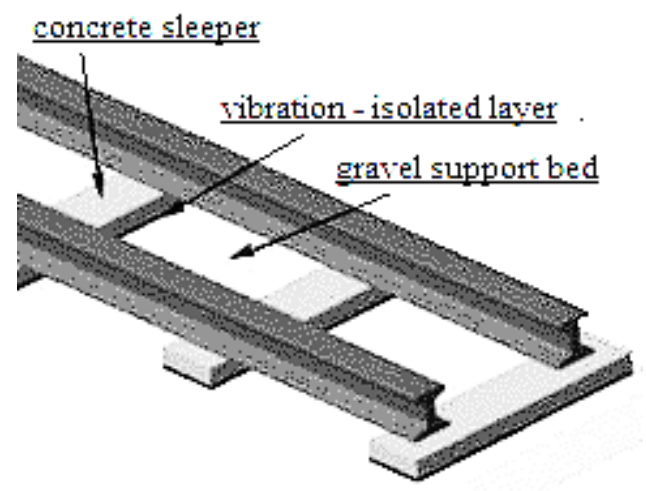

Fig. 1. Typical place of vibration - insulated concrete sleepers application.

Source: study based on http://www.amargo.pl/ dated 12-09-2015. 
The application of prestressed concrete railway sleepers with vibration - insulated layer is associated with a reducing the deformation of the tracks, especially the vertical deformation (KWIATKOWSKA E. 2011). The effect is an extended shelf life of the track, and thus, cost savings associated with repairs. There are two types of under sleeper pads, depend on stiffness, soft under sleeper pads used for lightly loaded rails and stiff under sleeper pads as vibration insulation for all transition zones, especially in varied traffic, but also for main and high - speed tracks (MÜLLER BORUTTAU F. H., KLEINERT U. 2001).

\section{Summary and conclusions}

Railway sleepers represents a very important load bearing, strengthening element of railway tracks. To increase the durability of concrete sleepers a variety of treatments are used, among others impregnation of wooden sleepers, or concrete sleepers prestressing. Furthermore to approximating the characteristics of concrete sleepers to the wooden, mainly due to the of vibration damping, it is possible to use an additional vibration insulation.

Problems, which are associated with disposal of the sleepers, in particular wooden considered as toxic, cannot be omitted. Sleepers impregnated with creosote oil, to avoid the health hazard, cannot be recycled but disposed only. As opposed to the wooden sleepers, those which are made of concrete can be used as recycled materials, for example, for road construction - and this can be an advantage of prestressed concrete sleepers over wooden one.

\section{Literature}

1. BASzKiewicz K., Selejdak J. 2015. Analysis of prefabricated railway sleepers made of concrete, Rozdział 20, Budownictwo ogólne. Zagadnienia konstrukcyjne, materiałowe i cieplno - wilgotnościowe, Dylla A. (red.), Wydawnictwa Uczelniane Uniwersytetu Technologiczno - Przyrodniczego w Bydgoszczy, Bydgoszcz (Analiza prefabrykowanych podkładów kolejowych wykonanych z betonu).
2. Czyczula W., Derkowski W., Chudyba Ł. 2015. Analysis of the main factors affecting the durability of railway sleepers, „Rynek Kolejowy” 10/2015 (Analiza podstawowych czynników wptywajacych na trwałość podkładów kolejowych).

3. Holewa J., Kusina E., Krasińska A. 2008. Hydrocarbon pollution of railway sleepers and their waste classification, „Nafta - Gaz” nr 3/2008 (Zanieczyszczenia węglowodorowe $w$ zużytych podkładach kolejowych i ich oznaczanie w celu klasyfikacji odpadów).

4. Jaworska A., MilczareK D., NAduK E. 2013. Impregnation of wooden railway sleepers including physico-chemical properties used in wood preservatives, „Problemy Kolejnictwa” - Zeszyt 161. (Impregnowanie drewnianych podkładów kolejowych z uwzględnieniem właściwości fizykochemicznych stosowanych środków ochrony drewna).

5. KlimecKA - TATAR D. 2015. Safety restrictions in the logistics of dangerous and toxic substances. Vol.7 No.2 Production Engineering Archives.

6. KrasińsKa A., KrÓl A., KUKULSKA - ZAJĄC E. 2014. Legal aspects of waste management of railway sleepers, „Chemik” 11/2014 (Aspekty prawne gospodarowania odpadowymi podkładami kolejowymi).

7. KWIATKOWSKA E. 2011. Vibration-insulated railway sleepers made of concreto, „Inżynier budownictwa” 11(89) (Betonowe podkłady kolejowe z wibroizolacja).

8. Müller - Boruttau F. H., Kleinert U. 2001. Besohlte Schwellen. "Eisenbahntechnische Rundschau" 3/2001.

9. PŁonKa P. 2009. Brilliant work accident, „Surowce i Maszyny Budowlane” 6/2009 (Genialny wypadek przy pracy).

10. SANCEWICZ S. 2010. Railway road surface, PKP Polskie Linie Kolejowe S.A., Warszawa (Nawierzchnia kolejowa). 